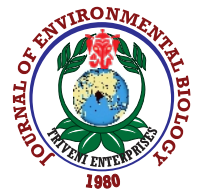

\title{
Optimization of enzymatic clarification of sapota (Achras sapota L.) juice using response surface methodology
}

\section{Baskar* and G. Hemalatha}

Department of Food Science and Nutrition, Community Science College and Research Institute, Tamil Nadu Agricultural University, Madurai-625014, India

*Corresponding Author Email : baskar.fsn@gmail.com

\section{Abstract}

Aim: The present study aimed to develop enzymatic clarified sapota (Achras sapota L.) juice beverage under optimized conditions for future scale up.

Methodology: In this study, the ripened sapota fruits PKM 1 variety were ground to pulp and pulp was mixed with $0.05-0.15 \%$ pectinase enzyme and incubated at $35^{\circ} \mathrm{C}$ $45^{\circ} \mathrm{C}$ for 30-120 min. After incubation period the enzyme was deactivated by placing the pulp in warm water bath at $90^{\circ} \mathrm{C}$ for $3 \mathrm{~min}$. Optimal enzymatic clarified juice was produced by pectinase enzyme by response surface methodology.

Results: The absorbance values decreased with increasing incubation time at fixed temperature. Incubation time showed a significant and $p<0.05$ negative effect on $L^{*}$ value at linear terms. At fixed temperature, the $L^{*}$ value increased with increasing enzyme concentration. Significant regression models proved that the changes in clarity, juice yield and colour ( $\mathrm{L}^{*}$ values) when compared to the independent variables demonstrated, coefficient of determination, $R^{2}$ greater than 0.8 .

Interpretation: Optimization conditions like minimum clarity, maximum juice yield and maximum color ( $\mathrm{L}^{*}$ value) can be applied in the production of sapota juice for commercial use.

Key words: Achras sapota, Clarified juice, Pectinase enzyme, Response surface methodology

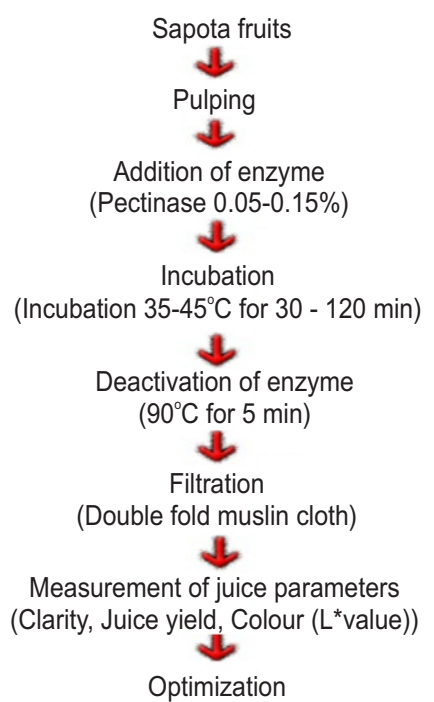

( $0.15 \%$ enzyme concentration at $45^{\circ} \mathrm{C}$ for $120 \mathrm{~min}$ )

Storage 


\section{Introduction}

India is one of the major producer of sapota fruits, followed by Mexico, Guatemala and Venezuela. India is the second largest producer in the production of Fruits and vegetable and its annual production is around 80,000 - $85,000 \mathrm{MT}$ from the area of about 6982 ha and productivity of 11.64 MT per hectare. Nutrient contents of sapota fruits consist $(21.49 \mathrm{~g})$ carbohydrates, $(0.7 \mathrm{~g})$ protein, $(1.1 \mathrm{~g})$ fat, $(73.7 \mathrm{~g})$ moisture, $(27 \mathrm{mg})$ phosphorus, (28 mg) calcium, (2 mg) Iron and (6 mg) ascorbic acid (Gopalan et al., 2005). Value added products like jams, jellies, osmodehydrated slices, sweet chutney, squash, sapota milk shake, dried sapota pieces, nectar, pickle, blended sapota drinks, candy and fermented wines are prepared from sapota. (Gautam and Chundawat, 1998). Sapota reduces inflammation and pain prevents gastritis, reflux oesophagitis and bowel disorders. Sapota strengthens the intestines, boosts immunity and prevents from bacterial infections as it is rich in Vitamin $\mathrm{C}$.

Pregnant women are advised to eaten sapota for high nutritional content as it reduces weakness, nausea and dizziness and prevents anaemia. It is also useful in constipation and piles (Baskar et al., 2020). As beverage industry is growing every year, it is necessary to develop technology for fruit juice based beverages with assured quality. Response surface methodology is a statistical method mostly used for optimizing products in the food industry (Frank, 2001; Luciane et al., 2001; Pietrasik and Lichan, 2002). It involves designing experiments, selecting variables in experimental design, fitting mathematical models and finally selecting variables by optimizing the response (Nithya et al., 2016). Using Design Expert Software, RSM can be performed for optimization of product ingredients.

Along with optimization, RSM can also be used to find the effect of correlation between the inputs on the response, wherein more than one response can be studied (Josephine et al., 2014). Response surface methodology, minimizes the number of experimental trials required to evaluate multiple parameters and their interactions. Recently, the clarified fruit juice products are in gread demand in the market. About 25 to 30 per cent of fruits and vegetables are lost annually post harvest due to spoilage, inadequate handling, transport, storage, lack of processing facilities and non-availability of market (Bhat, 2000).

During season, the selling price of sapota is less than Rs. $10 \mathrm{~kg}^{-1}$. Sapota juices are used as nutritional and nutraceutical health beverage, as they are rich in polyphenols. Enzymatically clarified sapota juice beverage can be used as a health promoting beverage because of its multifunctional properties (Kulkarni et al., 2007). In view of the above, this study was carried out to produce enzymatically clarified sapota juice by response surface methodology. Hence, an experiment was undertaken under optimized conditions (incubation time, temperature and enzyme concentration) for preparing of enzymatic clarified sapota juice using RSM.

\section{Materials and Methods}

The study was conducted in the Department of Food Science and Nutrition, Community Science College and Research Institute, Tamil Nadu Agricultural University, Madurai, India, during the year 2017 to 2020. Good quality and medium size fruits of sapota (Achras sapota L.) variety PKM 1 fruits were harvested, cleaned and allowed to ripen for one week at ambient temperature. The fruits were procured from the Horticultural College and Research Institute, Periyakulam, TNAU, Tamil Nadu, India. The ripened sapota fruits were washed, dried, peeled, deseeded and pulped using a food processor for two minutes. Commercial enzyme Pectinex Ultra SPL (Novozyme, Denmark) was used as clarifying agent for preparing clarified sapota juice. Fresh sapota pulp was mixed with $0.05-0.15$ per cent pectinase enzyme and incubated at $35^{\circ} \mathrm{C}-45^{\circ} \mathrm{C}$ for $30-120$ minutes (Vijayanad, et al., 2010; Relekar et al., 2011). After incubation period, sapota fruit pulp enzyme content was deactivated through water bath at the temperature of $90^{\circ} \mathrm{C}$ for $5 \mathrm{~min}$. From the sapota pulp, juice was filtered through double fold muslin cloth and the juice was extracted and used for further treatments.

Clarity: The pectin molecules was breakdown by pectolytic enzymes, which make easy the formation of pectin-protein flocs, leaving a pure supernatant and extensively removing the colloidal phase of the juices. In the clarified juice, clarity is an important index. Clarity value was measured on a Elico UV-VIS spectrophotometer (SL 210 UV VIS spectrophotometer, Japan) and the absorbance was read at $660 \mathrm{~nm}$. In a sample distilled water were used as reference.

Juice yield: Clarified sapota juice yield was estimated as a percentage of juice obtained from a unit weight of the sample. Sapota juice yield was calculated by the following formulae:

$$
\text { Juice yield } \%=\frac{\text { Weight of clear juice }}{\text { Weight of sample }{ }^{*} 100}
$$

Colour ( $L^{*}$ value): Hunter Laboratory Calorimeter (model SN 7877, Ultrascan, Hunter Associates Laboratory, Inc., Virginia) was used to measure the colour $\left(\mathrm{L}^{*}\right)$ value of the clarified juice (Sin et al., 2006). where + LÕ is the lightness and $L$ is the darkness (Busch-Kschiewan et al., 2004). To measure the colour value of the samples, the instrument was first calibrated by keeping black and white standard pieces. The standard value was measured and followed by the sample colour value was measured by filling the fruit juice in the transparent pieces and values were noted. Change in the colour values from the samples to the standard were observed and recorded.

The mean of three trials was reported. Observed colour ( $L^{*}$ values) showed lightness / darkness and ranged from 0 (black) to 100 (white) with upper values corresponding to more lightness. Object's colour dimensions namely as $a^{*}$ and $b^{*}$ values, $a^{*}$ indicated red $(+a)$ to greenness $(-a)$ and $b^{*}$ indicated yellow 
$(+b)$ to blueness (-b). Higher $a^{*}$ values indicated more redness while higher $b^{*}$ values indicated more yellowness.

Experimental design: In this experiment, optimized conditions for the enzymatic clarification of sapota juice was determined by Response Surface Methodology (RSM). It highlights the modeling and analysis of the problem where response of interest is subjective by several variables and the objective is to optimize this response by Montgomery (2008). For designing this experiment, a central composite design was employed. D - Optimal Design was used to study the interaction of process variables by applying RSM (Bezerra, 2008). Response surface methodology is a number of experimental trials needed to provide sufficient information for statistically suitable results. A five-level and three-factor central composite rotatable design was used by Myers \& Montgomery (2002). In this experiment, the lowest and highest values for effect of enzyme concentration $0.05 \%$ to $0.15 \%$, incubation time were set at 30 to 120 min and temperature at $35^{\circ} \mathrm{C}$ to $45^{\circ} \mathrm{C}$.

Statistical analyses were carried out by using ECHIP Software Version 6. (Echip Inc., Hockessin, Delaware, USA) (Echip Software, 1993). A central composite rotational design was used in the experiment by Cochran and cox (1957) to study the combined effect of three independent variables, i.e., incubation time, temperature and enzyme concentration. X1, X2, and $X 3$ are the three independent variables. An_1, 0, and +1 three levels were called as independent variables. These three independent and dependent variables were used for the treatment of enzyme clarified juice (Baumann, 1981). Nineteen combinations and five replicates were used in random order and followed to a CCD design for these selected variables. Clarity $\left(\mathrm{y}_{1}\right)$, juice yield $\left(\mathrm{y}_{2}\right)$ and color $\left(\mathrm{L}^{*}\right)$ value $(\mathrm{y} 3)$ were used to measure the dependent variables $(y)$ for sapota juice. Three dependent variables and Independent variables were expressed as response function separately, as follows.

$$
\begin{aligned}
& Y_{0}=b_{0}+b_{1} x_{1}+b_{2} x_{2}+b_{3} x_{3}+b_{12} x_{1} x_{2}+ \\
& b_{13} x_{1} x_{3}+b_{23} x_{2} x_{3}+b_{11} x_{1}^{2}+b_{22} x_{2}^{2}+b_{33} x_{3}^{2}
\end{aligned}
$$

In this experiment, data were expressed as b0 (constant term), $b_{1}, b_{2}$ and $b_{3}$ (linear coefficient), $b_{11}, b_{22}$ and $b_{33}$ (quadratic coefficient), and $b_{1}{ }^{2}, b_{1}{ }^{3}$ and $b_{2}{ }^{3}$ (interactive coefficient). The polynomial functions and its importance were expressed as statistically using F-value at a probability level of $0.001,0.01$ or 0.05 . Contour maps produced from the regression models were graphically expressed by regression coefficients. One variable constant at the center point and other variables within the experimental range were used to produce graphical three dimensional (3D) plots.

\section{Results and Discussion}

$\mathrm{R}^{2}$, is the ratio of the variation explained by the given independent variables to the total variation. Also it establishes the degree of fit i.e., coefficient of determination, (Haber and Runyon, 1977). Coefficient of determination is also the measure of the variability in the response variables and accounts for the regression analysis (Mclaren et al., 1977). Unity and better empirical model fits the actual data in $\mathrm{R}^{2}$. Behaviour variation explaining minor value of $R^{2}$, less consequence and dependent variables in the model were used. Table 2 showes that the response surface model developed for all the response variables were satisfactory from the analysis of variance in these three variables. The $R^{2}$ values were more than 0.8 , its stated that the regression models in the response variables were well explained in this study.

The concentration of enzyme as its linear effect was negative and its quadratic effect was positive for clarity. Interaction effect between incubation time and enzyme concentration at $p<0.05$ was positive and significant, The enzyme concentration and incubation time were main reason for clarity. At fixed temperature, enzyme concentration and time showed clarity (Fig.1). Absorbance values were decreased, indicating that there is an increase in enzyme concentration. Less absorbance value was observed at more enzyme concentration. The clarified sapota juice recorded Lower absorbance values. Increase in enzyme concentration resulted in increased rate of clarification, reduced electrostatic magnetism between the particles. These particles aggregated to larger particles which eventually settled down exposing the part of the positively charged protein beneath. Increasing incubation time at fixed temperature decreased the absorbance values.

The linear negative effect (Table 1) of incubation time at $p<0.01$ level was leading. Incubation time, temperature and enzyme concentration are important factors for obtaining to clear clarified juice (Kilara, 1982). The model F value was highly significant $(p<0.0001)$ as showed by the analysis of variance. The higher $F$ value could occur due to noise at $0.01 \%$. Probability $>$ of $F$ value lesser than 0.05 indicated that estimated model are significant. Higher clarified juice yield was obtained from the following conditions (coded form): Enzyme concentration was used to $0.15 \mathrm{~g} / 100 \mathrm{~g}, 120$ minutes incubation time at $45^{\circ} \mathrm{C}$ incubation temperature. Results also stated same that the enzymatically hydrolyzed clarified guava juice yield was increased and it can be due to the action of the pectinases in the guava pulp. It also Increased the clarified juice yield due to the action of pectinases humiliate pectic substances (Pilnik\&Voragen, 1993; Diwan\&Shukla, 2005). The first judgement of a clarified juice quality is colour. clarified juice colour ( $L^{*}$ value) measures the lightness of the product and the value ranges should be as high as possible. The clarified juice product was dark coloured meaning that it is deterioriating the product and less appealing by the consumers. In this experiment, incubation time showed a significant level $p<0.05$ and a negative effect on colour ( $L^{*}$ value) at linear terms. The clarified juice colour $\left(\mathrm{L}^{*}\right)$ value at fixed temperature with enzyme concentration and incubation time are presented in Fig. 3. The colour ( $L^{*}$ value) of the clarified juice were gradually increased with increase in enzyme concentration at constant temperature. 
Table. 1: Effect of incubation time, temperature and enzyme concentration on three dependent variables for enzymatic clarified sapota juice

\begin{tabular}{llllll}
\hline & Independent variables & & \multicolumn{2}{l}{ Dependent variables } \\
\hline Time (Minutes) & Temperature $\left({ }^{\circ} \mathrm{C}\right)$ & Enzyme conc. $(\%)$ & Clarity (abs) & Juice Yield (\%) & Color (L*value) \\
\hline$X_{1}$ & $\mathrm{X}_{2}$ & $\mathrm{X}_{3}$ & $\mathrm{~b}_{1}$ & $\mathrm{~b}_{2}$ & $\mathrm{~b}_{3}$ \\
75.00 & 40.00 & 0.10 & 0.2236 & 55 & 35.94 \\
30.00 & 45.00 & 0.05 & 0.3228 & 51 & 33.54 \\
120.00 & 45.00 & 0.05 & 0.1795 & 56 & 36.87 \\
30.00 & 35.00 & 0.05 & 0.3114 & 49 & 32.65 \\
30.00 & 35.00 & 0.15 & 0.2931 & 53 & 31.33 \\
75.00 & 31.59 & 0.10 & 0.2509 & 54 & 34.05 \\
120.00 & 35.00 & 0.05 & 0.1795 & 56 & 36.58 \\
75.00 & 40.00 & 0.10 & 0.2245 & 56 & 35.94 \\
75.00 & 48.41 & 0.10 & 0.2416 & 58 & 34.98 \\
150.68 & 40.00 & 0.10 & 0.1934 & 58 & 37.62 \\
120.00 & 45.00 & 0.15 & 0.1495 & 61 & 39.28 \\
75.00 & 40.00 & 0.10 & 0.2235 & 55 & 35.63 \\
75.00 & 40.00 & 0.10 & 0.2445 & 55 & 35.94 \\
75.00 & 40.00 & 0.18 & 0.3217 & 59 & 34.96 \\
75.00 & 40.00 & 0.15 & 0.1502 & 59 & 33.56 \\
30.00 & 35.00 & 0.15 & 0.3012 & 57 & 38.77 \\
75.00 & 45.00 & 0.10 & 0.2132 & 55 & 35.45 \\
75.00 & 40.00 & 0.10 & 0.2131 & 56 & 35.63 \\
\hline
\end{tabular}

Table. 2: Regression coefficient, R2 and Probability values for three responses for clarification of sapota juice

\begin{tabular}{llll}
\hline Regression coefficient & Clarity (abs) & Juice yield (\%) & Colour (L*value) \\
\hline$b_{0}$ & 0.44527 & 74.47332 & 17.10309 \\
$b_{1}$ & -2.47404 & 0.28740 & 0.16111 \\
$b_{2}$ & 1.29075 & -1.94811 & 0.53926 \\
$b_{3}$ & -1.24083 & -17.36977 & -56.73834 \\
$b_{1}{ }^{2}$ & 1.00300 & -7.18792 & -2.46809 \\
$b_{2}$ & 1.19857 & 0.026631 & -5.35441 \\
$b_{3}^{2}$ & 5.33123 & -16.53609 & -89.60659 \\
$b_{12}$ & -1.2222 & -2.2222 & -2.33889 \\
$b_{13}$ & -1.07778 & -0.1111 & 0.22278 \\
$b_{23}$ & -2.0000 & 2.0000 & 1.72500 \\
$R^{2}$ & 0.9133 & 0.9159 & 0.9035 \\
P or probability & 0.0000 & 0.0000 & 0.0000 \\
\hline
\end{tabular}

${ }^{*}$ Significant at 0.001 level; ${ }^{* *}$ Significant at 0.01 level and ${ }^{* * *}$ Significant at 0.05 level

The clarified juice colour ( $L^{*}$ value) decreased initially up to $80 \mathrm{~min}$ and later gradually increased due to formation of protein-tannin complex as incubation time increased. In this experiment, the most important factor was enzyme concentration and influenced the clarification of sapota fruit juice and its enzymatic treatment. Temperature was the least significant variable and it did not show significant effects on linear, quadratic and interactive regressions model in the clarified juice. In this study, moderate temperature were used for the preparation of enzymatic clarification of sapota juice. In this experiment, optimum clarification condition of juice was explained by superimposing contour plots for three response variables. It was found that there is the good resulted treatment combination from the variables and its related to the response variable functions (clarity, juice yield and color) and cost of the enzyme were to be found. In this experiment, enzyme treatment was found most suitable for the optimum condition to prepare clarification of sapota juice through superimposing the contour plots of all three response variables (Sin et al., 2006; Vandana et al., 2006; Vijayanad, et al., 2010; Norjana et al., 2011). It is revealed that the final condition were to be considered optimum if the absorbance value were as low as possible while the clarity value, 


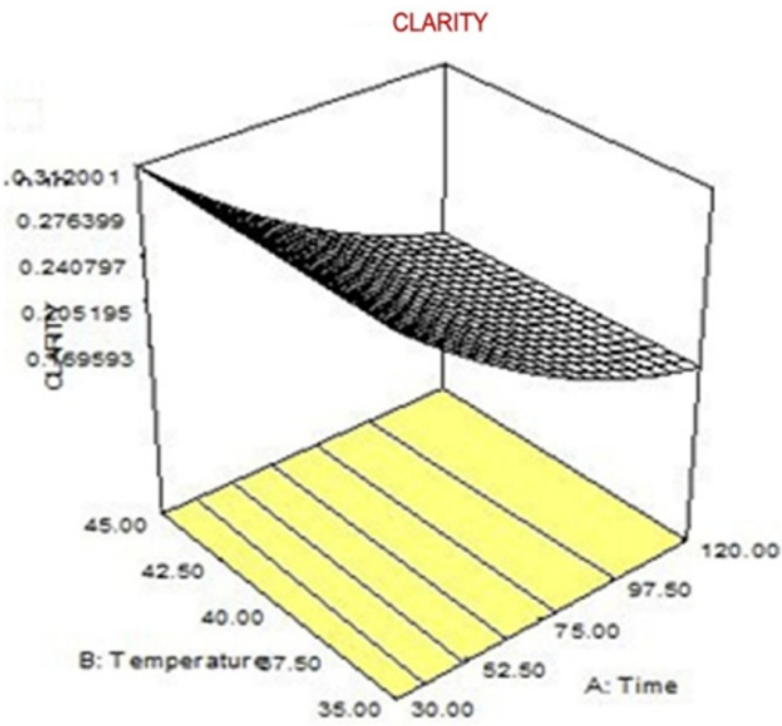

Fig. 1: Response surface for clarity of sapota juice as a function of temperature and enzyme concentration for 120 min at $45^{\circ} \mathrm{C}$.

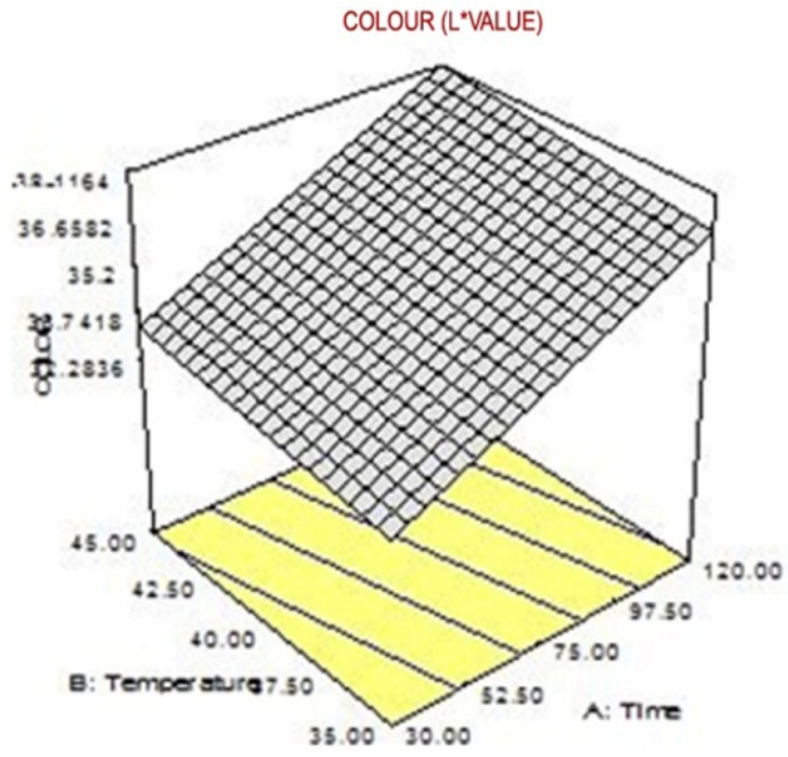

Fig. 3: Response surface for color $L^{*}$ value of sapota juice as a function of temperature and enzyme concentration for $120 \mathrm{~min}$ at $45^{\circ} \mathrm{C}$.

colour ( $L^{*}$ value) absorbance value were slightly high and juice yield was as high as possible. In this experiment, graphical optimization parameter were found as follows: (a) minimum clarity (b) maximum juice yield and (c) maximum color ( $L^{*}$ value). The response function like clarity, juice yield and color $\left(L^{*}\right.$ value (Figs. 1-3)) were computer generated plot and using the

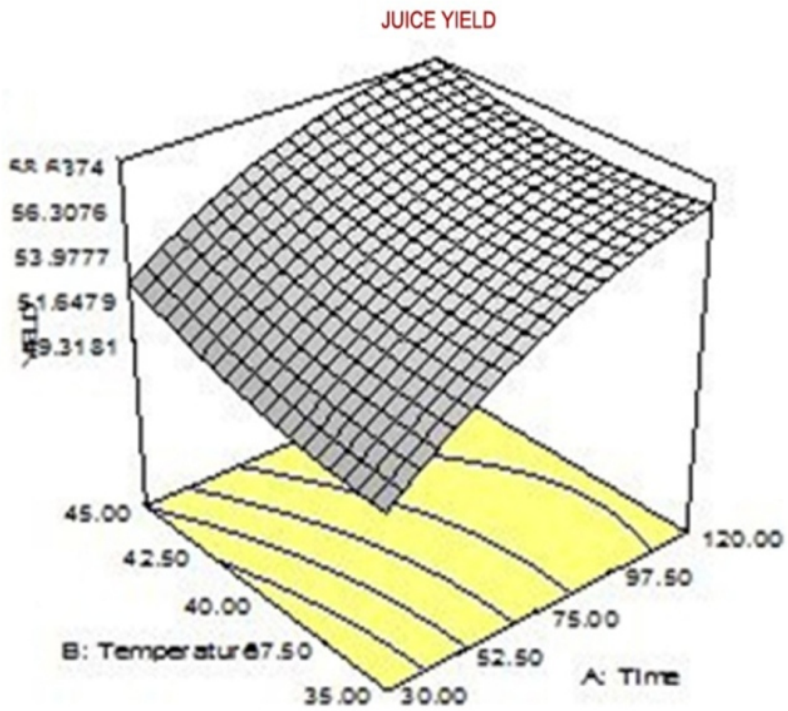

Fig. 2: Response surface for yield of sapota juice as a function of temperature and enzyme concentration for 120 min at $45^{\circ} \mathrm{C}$.

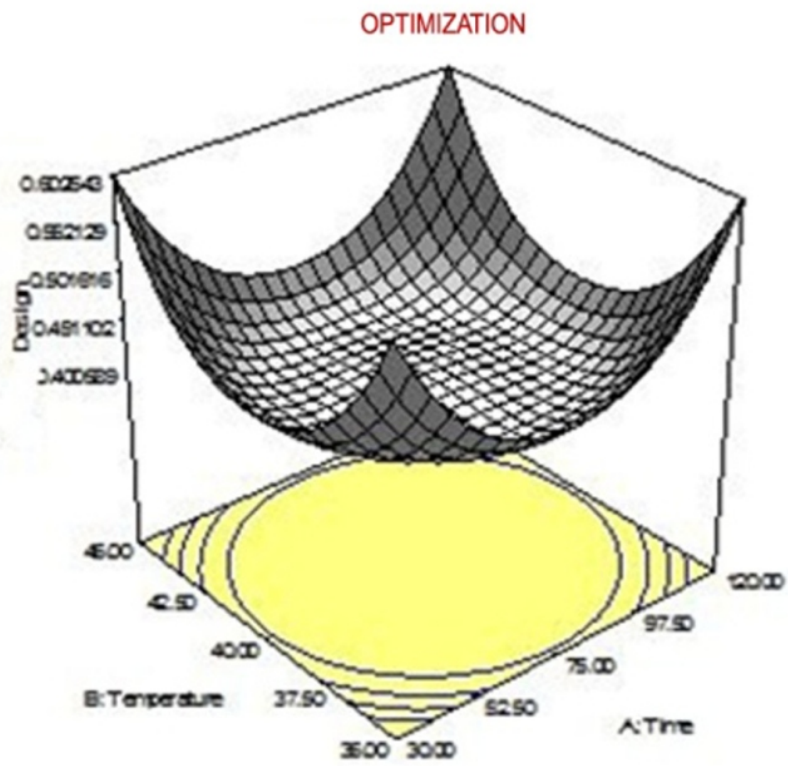

Fig. 4: Response surface for optimization of sapota juice as a function of temperature and enzyme concentration for $120 \mathrm{~min}$ at $45^{\circ} \mathrm{C}$.

parameter for an optimum condition of the superimposed plot as shown in Fig. 4. The response function variables were selected as the important index of the physical parameters (clarity, juice yield and color ( $L^{*}$ value) of the clarified juice. (Figs. $\left.1-3\right)$, graphical representation of the optimum conditions for the response function variables, while the optimum combined condition for the 
clarification of sapota juice was found to be at $0.15 \%$ enzyme concentration at $45^{\circ} \mathrm{C}$ for 120 min as shown in Fig. 4 .

The increasing demand for soft drinks offers a great scope for development of natural nutrient rich beverages. These drinks help the consumers in having an option which has negligible synthetic chemicals and also has immense health benefits. The growing consumer awareness particularly with regard to health benefits of the products consumed has led to an exponential growth in the demand for food and also beverages made from natural sources that contain ingredients preferably having nutraceutical properties. As a ready to serve beverage with distinct sapota flavor and taste, the technology can be widely adopted from the food and beverage industry where the enzyme clarified juice has ready marketability.

\section{Acknowledgment}

The authors are thankful to the University Grants Commission, New Delhi, India for the financial support for the award of Post doctoral research fellowship scheme.

\section{Add-on Information}

Authors' contribution: M. Baskar: Carrying this research and preparation of manuscript; $\mathbf{G}$. Hemalatha: Guided for manuscript preparation and statistical analysis.

Research content: The research content of manuscript is original and has not been published elsewhere.

\section{Ethical approval: NotApplicable}

Conflict of interest: The authors declare that there is no conflict of interest.

\section{Data from other sources: NotApplicable}

Consent to publish: All authors agree to publish the paper in Journal of Environmental Biology.

\section{References}

Abdullah, A.G.L., N.M. Sulaiman, M.K. Aroua and M.J.M. Noor: Response surface optimization of conditions for clarification of carambola fruit juice using a commercial enzyme. J. Food Enginee., 81, 65-71 (2007).

Baskar, G. Hemalatha and P. Muneeshwari: Traditional and medicinal importance of sapota - Review. Int. J. Curr. Microbio. Appl. Sci., 9 , 1711-1717 (2020).

Baumann, J.W.: Application of enzymes in fruit juice technology. In: Enzymes and food processing (Eds.: G.G. Birch, N. Blakebrough and K.J. Parker). London. Applied Science Publication, pp. 129-147 (1981).

Bezerra, M., R. Santelli, E. Oliveira, L. Villar and L. Escaleira: Response surface methodology (RSM) as a tool for optimization in analytical Chemistry. Talanta, 76, 965-977 (2008).

Bhat, M.K.: Cellulases and related enzymes in biotechnology. Biotechnol. Adva., 18, 355-383 (2000).

Busch-Kschiewan, K., J. Zentek, F.J. Wortmann and V. Biourge: UV light, temperature, and humidity effects on white hair color in dogs. $J$. Nutri., 134, 2053S-2055S (2004).

Cochran, W.G. and G.M. Cox: Some methods for the study of response surfaces. In Experimental Designs. $2^{\text {nd }}$ edn., New York: John Wiley and Sons Inc., pp. 335-375 (1957).

Diwan, A. and S.S. Shukla: Process development for the production of clarified guava juice. J. Food Sci. Technol., 42, 245-249 (2005).

Echip software-version 6.0 windows. Wheeler, B. Reference Manual. Echip Inc.: Hockessin, Delaware, USA. Food Chemistry, 51, 83-88 (1993).

Frank, R.: Blending response surface methodology and principal components analysis to match a target product. Food Qual. Prefer., 12, 457-465 (2001).

Gautam, S.K. and B.S. Chundawat: Standardization of technology of sapota wine making. Indian Food Packer, 52, 17-21 (1998).

Haber, B., V.A. Runyon and R. General Statistics. $3^{\text {rd }}$ Edn., Reading, MA: Addison-Wesley Publishing Company (1977).

Josephine, S.N., A. Singh and G. Baskar: Osmotic dehydration of fruits An integrated approach, Int. J. Food Nutri. Sci., 3, 18-23 (2014).

Kilara, A.: Enzymes and their uses in the processed apple industry: A review. Proc. Bioche., 23, 35-41 (1982).

Kulkarni, A.P., R.S. Policegoudra and S.M. Aradhya: Chemical composition and antioxidant activity of sapota (Achras sapota L.) fruit. J. Food Bioche., 31, 399-414 (2007).

Lee, W.C., S. Yusof, N.S.A. Hamid and B.S. Baharin: Optimizing conditions for enzymatic clarification of banana juice using response surface methodology (RSM). J. Food Enginee., 73, 55-63 (2006).

Luciane, C.M., C.M. Hilary, M. Aparecida and A.P. De Silva: Optimization of the roasting of robusta coffee (C. Canephora conillon) using acceptability tests and RSM. Food Qual. Prefer., 12, 153-162 (2001)

Mclaren, C.G., V.I. Bartolome, M.C. Carrasco, L.C. Quintana, M.I.B. Ferino and J.Z. Mojica: Experimental design and data analysis for agricultural research. Vol. 1. Los Banos, Laguna: International Rice Research Institute (1977).

Montgomery, D.C.: Design and Analysis of Experiments. New York: Wiley, 416-419 (2008).

Myers, R. and D.C. Montgomery: Response Surface Methodology. New York, USA: Wiley. Novo Nordisk Ferment, Ltd., Dittingen, Switzerland. Fruit and Vegetable Product Sheet. (2002).

Nithya, D.J., K.A. Basco, M. Saravanan, R.J. Mohan and K. Alagusundaram: Optimization of process variables for extrusion of Rice-Bengal gram blends. Indian J. Sci. Indust. Res., 75, 108-114 (2016).

Norjana, I. and A.A. Noor Aziah: Quality attributes of durian juice after pectinase enzyme treatment. Int. Res. J., 18, 3 (2011)

Pietrasik, Z., and E.C.Y. Li-Chan: Response surface methodology study on the effects of salt, microbial transglutaminase and heating temperature on pork batter gel properties. Food Res. Int., 35, 87-396 (2002)

Pilnik, W., and A.G.J. Voragen: Pectic enzymes in juice manufacture. In: Enzymes in food processing (Eds.: T. Nagodawitana and G. Reed), New York: Academic (1993).

Rai, P., G.C. Majumdar, S.D. Gupta and S. De: Optimizing pectinase usage 
in pretreatment of mosambi juice for clarification by response surface methodology. J. Food Enginee., 64, 397-403 (2004).

Relekar, P.P., A.G. Naik and B.V. Padhiar: Qualitative changes in valueadded products of sapota cv. Kalipatti during storage. Indian J. Horticul., 68, 413-418 (2011).

Sin, H.N., S. Yusof, N.S. Abdul Hamid and R. Abd. Rahman: Optimization of enzymatic clarification of sapodilla juice using response surface methodology. J. Food Enginee., 73, 313-319 (2006).

Vandana, T.D.G. and D. Kumar: Optimization of enzyme concentration reaction time and temperature for carrot juice extraction. J. Food Sci. Technol., 43, 470-473 (2006).

Vijayanand, P., S.G. Kulkarni and G.V. Prathibha: Effect of pectinase treatment and concentration of litchi juice on quality characteristics of litchi juice. J. Food Sci. Technol., 47, 235-239 (2010). 